\title{
Effectiveness of Using Information, Education, and Communication Flowchart Media in Implementation of Early Breastfeeding Initiation
}

\author{
Rizna Notarianti ${ }^{1 *}$, Sandra Fikawati1 ${ }^{1}$, Alifani Faiz Faradhila²
}

\begin{abstract}
${ }^{1}$ Department of Nutrition, Faculty of Public Health, Universitas Indonesia, Depok, Indonesia, 2Program of Reproductive Health, Faculty of Public Health, Universitas Indonesia, Depok, Indonesia
\end{abstract}

\begin{abstract}
Early initiation of breastfeeding (EIB) has many benefits for both the baby and the mother. However, in Bogor City, there are still many babies who do not get EIB when they are born (33.6\%). The implementation of EIB is not optimal due to the absence of standard procedures to equalize its theory and perception. This study aimed to investigate the effectiveness of using Information, Education, and Communication (IEC) flowchart media concerning the standard procedure for EIB implementation in the Primary Health Care (PHC) in Bogor City. A quasi-experimental research was conducted on 58 midwives divided into the intervention and control groups. The intervention group was given IEC flowchart media, the EIB standard procedure, whereas the control group was given a brief explanation about EIB. The results indicated that the intervention group (96.0) had a higher average EIB implementation score than the control group (84.7). Furthermore, the success rate of EIB was higher in the intervention group (93.1\%) than in the control group (20.7\%). In conclusion, the IEC flowchart media is effectively used to optimize EIB implementation by midwives in the PHC in Bogor City.
\end{abstract}

Keywords: early initiation of breastfeeding, flowchart, information, education and communication media, standard procedure

\section{Introduction}

The infant mortality rate is an important indicator of public health and quality of life in a country. The most vulnerable stage of child survival is the neonatal period, 28 days after birth, and has the highest risk of death. ${ }^{1}$ Two-thirds of neonatal deaths occur during the perinatal period, 0-7 days after birth. ${ }^{2}$ The global data indicates that the infant mortality rate in the world tends to decline from 37 deaths per 1000 live births to 18 deaths per 1000 live births during 1990-2017. ${ }^{3}$ Furthermore, the World Health Organization (WHO) stated that the neonatal mortality rate of the Southeast Asian regions is 14 per 1000 live births. In Indonesia, the neonatal mortality rate in 2017 was 12.4 per 1000 live births. ${ }^{4}$ This figure is still relatively high compared to several other countries in other Southeast Asian regions.

Neonatal mortality rates are closely related to infectious diseases caused by bacteria or parasites, such as respiratory tract and gastrointestinal infections. The disease can be prevented by administering colostrum immediately after giving birth through early initiation of breastfeeding (EIB). 5,6 The EIB is one of the interventions that can reduce the risk of neonatal death and make exclusive

Correspondence*: Rizna Notarianti, Department of Nutrition, Building $F$, 2nd Floor, Faculty of Public Health, Universitas Indonesia, Depok, West Java, Indonesia, E-mail: riznanotarianti@gmail.com, Phone: +62 819-0425-1396 breastfeeding successful. ${ }^{7-9}$ The EIB also prevents hypothermia in newborns, 10 and can reduce the risk factors for neonatal mortality by $22 \%, 11$; it also increases the chance of exclusive breastfeeding by eight times for up to 4 or 6 months compared with no EIB. In addition, EIB can strengthen the bond between the mother and the baby, ${ }^{12}$ and help the mother prevent pre-lacteal feeding. ${ }^{13}$

The global prevalence of children below six months being exclusively breastfed is $43 \%$, and $55 \%$ of newborns do not undergo EIB in the first one hour of life. ${ }^{14}$ In Indonesia, the scope of exclusive breastfeeding of children below six months decreased 54\% in 2016 to $46.7 \%$ in 2017; moreover, the EIB coverage was less than one hour in 2017 was $51.3 \%$, and those who did not do EIB by $42 \% .15$ The role of midwives during childbirth is very vital. The support midwives give to pregnant women will determine the success of EIB implementation and exclusive breastfeeding, especially midwives working in primary health care (PHC). ${ }^{16,17}$

The presence of midwives is an important factor in the successful implementation of EIB. ${ }^{18}$ The provision of midwife support to pregnant women was found to increase the success of EIB implementation by 17.5 
times. ${ }^{19}$ The first hour after birth is crucial for midwives to perform EIB. The implementation of EIB is successful if it is carried out as soon as possible after delivery, and the process lasts for 60 minutes or more. During breastfeeding, the baby is placed on the mother's chest, and the midwife should ensure that the baby comes into skin-toskin contact with the mother, finds the nipple, and drinks colostrum from the mother or the breast milk that first comes out. ${ }^{10}$

The Indonesian Midwives Association has established 58 steps for the Normal Childbirth Care program, in which EIB is included in the sequence of procedures, e.g., in step 43. However, in practice, not all midwives perform EIB optimally. According to Legawati, 20 some midwives who did not practice EIB had several reasons: impatience, need for more time, and difficulty implementing EIB. Currently, in Indonesia, EIB is confusing not only for health workers but also for the community. Information, Education, and Communication (IEC) media regarding EIB has not yet been provided optimally; thus, postpartum mothers do not know about EIB. ${ }^{21,22}$

The implementation of EIB in some health facilities is not optimal and is still hampered by many factors. The standard operating procedure of providing support to the EIB implementation is still limited.9,23 Furthermore, the $\mathrm{PHC}$ has not yet set a standard procedure to equalize the perception between the theory and the implementation of EIB; thus, health workers only provide EIB services according to their individual abilities. The implementation of EIB by midwives in healthcare facilities, especially in hospitals and other health centers, is still inadequate; some midwives still perform EIB not following the existing stages. 24,25

In 2018, IEC media was developed in the form of a flow chart regarding the procedure for the EIB implementation (hereinafter referred to as "IEC flowchart media of EIB"). ${ }^{26}$ The result of the study conducted in six PHCs in East Jakarta indicated a significant difference in the EIB implementation scores between the group given the information, education, and communication (IEC) flowchart media and the control group. The intervention group had a better score of $97.4(84.4-100.0)$ than the control group with 78.3 (71.9-90.6). The use of this media also increased the implementation of EIB by midwives by up to $95.2 \% .^{26}$

The Health Profile of West Java in 2016 revealed that the coverage of exclusive breastfeeding in the West Java Province was $46.4 \%$, whereas that in Bogor City was $53.3 \% .27$ Based on the National Basic Health Research/Riset Kesehatan Dasar (Riskesdas) data in 2013, the percentage of EIB implementation in less than one hour in the West Java Province was only $35.7 \%$. In contrast, the EIB coverage in PHC in Bogor City was $33.6 \% .^{28}$ This study aimed to determine the differences in the score of the EIB implementation between the intervention and control groups and confirm the effectiveness of using the IEC flowchart media, ${ }^{26}$ in improving the implementation of EIB in the PHC in Bogor City.

\section{Method}

This study adopted a quantitative and quasi-experimental research design. It was conducted in FebruaryJune 2018 on 58 midwives from eight PHCs in Bogor City. Each group consisted of 29 midwives selected via purposive sampling based on subjective and practical considerations following the predetermined criteria. The inclusion criteria were as follows: 1) having experience assisting with childbirth during the study period and 2) having a midwifery diploma. The intervention group consisted of midwives who served at the Tanah Sareal PHC, Pasir Mulya PHC, Cipaku PHC, and Merdeka PHC. The control group consisted of midwives from the East Bogor PHC, Central Bogor PHC, North Bogor PHC, and Tegal Gundil PHC.

This study used a questionnaire to determine the age, educational background, work period, training, and knowledge of midwives; assessment form and IEC media were the additional instruments used. The participants in the intervention group received education in the form of IEC media containing a flowchart of the EIB implementation procedure printed on a poster and booklet with the registration numbers Intellectual Property Rights (IPR) 10417/UN2.F10.D/PPM.00.01/2018 and 10416/UN2.F10.D/PPM.00.01/2018, respectively. The participants in the control group, which was a comparison group, received education and a brief explanation about EIB but did not receive the IEC flowchart media.

In this study, the EIB implementation is considered successful if the baby can reach the mother's nipple and suckle until they are satisfied and falls asleep without intervention according to the procedure. The EIB score was obtained from the EIB implementation assessment form. Data collection was performed by 12 enumerators who were previously trained about the standard procedure of EIB and how to retrieve data in the field. All of the enumerators had a midwifery education background. Each enumerator must be in the PHC for 24 hours (standby) with a shift system adjusted to each PHC to assess the EIB implementation by midwives at the time of delivery.

Descriptive statistics were used to determine the respondents' characteristics (age, educational background, work period, training, and knowledge of midwives). An independent t-test was employed to determine the difference between the EIB score and the EIB success category in the intervention and control groups. The linear regression method was employed to determine the effect of independent variables on the EIB implementation. 


\section{Results}

Table 1 presents an overview of the respondents' characteristics. In the intervention group, most of the respondents were $\leq 35$ years old, had a Diploma-III (DIII) education, had worked for 12 years or less, and attended training related to EIB. Statistically, no significant differences were observed in the characteristics of the midwives between the two groups, except for knowledge. The control group respondents had better knowledge than the intervention group.

Table 2 compares of the average EIB implementation score between the intervention and control groups. The Independent $t$-test results indicated a significant difference in the EIB implementation score between the intervention and control groups. Table 2 demonstrates that the average EIB implementation score of the intervention group was higher (96.0) than that of the control group (84.7). The minimum and maximum scores obtained by the intervention group were also higher (87.5-95.0) than that of the control group (78.1-93.8). In the intervention group, $62 \%$ of the respondents scored more than 95.0, whereas, in the control group, the majority scored 87.5.
In general, the number of midwives that successfully performed EIB was higher in the intervention group $(93.1 \%)$ than in the control group $(20.7 \%)$. This study also demonstrated the successful implementation of EIB; in the intervention group, $65.5 \%$ of the midwives successfully performed EIB within one hour. After the first hour had passed, an increase of $26.7 \%$ in the success of the EIB implementation in the intervention group was observed, whereas there was no increase in the control group (Table 3).

The result of the multivariate analysis indicated that $63.6 \%$ of the successful EIB implementations were influenced by the use of the IEC flowchart media, age, education, work period, and training. In contrast, other factors influenced the rest $(36.4 \%)$. The test results also revealed that the IEC flowchart media was the most dominant factor in implementing EIB, with a p-value of less than 0.05. The use of the IEC flowchart media increases the success rate of the EIB implementation by 11 times (Table 4).

\section{Discussion}

The characteristics of the respondents in the interven-

Table 1. Distribution of Respondents by Age, Education, Work Period, Training, and Knowledge to the Intervention and Control Groups

\begin{tabular}{|c|c|c|c|c|c|c|}
\hline \multirow{2}{*}{ Variable } & \multirow{2}{*}{ Category } & \multicolumn{2}{|c|}{ Intervention Group } & \multicolumn{2}{|c|}{ Control Group } & \multirow{2}{*}{ p-value } \\
\hline & & $n=29$ & $\%$ & $\mathrm{n}=\mathbf{2 9}$ & $\%$ & \\
\hline \multirow[t]{2}{*}{ Age } & $>35$ years old & 9 & 31 & 14 & 48.3 & \multirow[t]{2}{*}{0.186} \\
\hline & $\leq 35$ years old & 20 & 69 & 15 & 51.7 & \\
\hline \multirow[t]{2}{*}{ Education } & DIV & 5 & 17.2 & 10 & 34.4 & \multirow[t]{2}{*}{0.139} \\
\hline & DIII & 24 & 82.8 & 19 & 65.6 & \\
\hline \multirow[t]{2}{*}{ Work period } & $>12$ years & 10 & 34.5 & 13 & 44.8 & \multirow[t]{2}{*}{0.430} \\
\hline & $\leq 12$ years & 19 & 65.5 & 16 & 55.2 & \\
\hline \multirow[t]{2}{*}{ Training } & Ever & 18 & 62 & 12 & 41.3 & \multirow[t]{2}{*}{0.119} \\
\hline & Never & 11 & 38 & 17 & 58.7 & \\
\hline \multirow[t]{2}{*}{ Knowledge } & Good & 8 & 27.6 & 20 & 69 & \multirow[t]{2}{*}{$0.001 *$} \\
\hline & Insufficient & 21 & 72.4 & 9 & 31 & \\
\hline
\end{tabular}

Note: *p-value $<0.05$, DIV = Diploma-IV, DIII = Diploma-III

Table 2. Early Initiation of Breastfeeding Implementation Score of the Intervention and Control Groups

\begin{tabular}{|c|c|c|c|c|c|c|}
\hline \multirow{2}{*}{ Variable } & \multirow{2}{*}{ Category } & \multicolumn{2}{|c|}{ Intervention Group } & \multicolumn{2}{|c|}{ Control Group } & \multirow{2}{*}{ p-value } \\
\hline & & $\mathrm{n}=\mathbf{2 9}$ & $\%$ & $n=29$ & $\%$ & \\
\hline \multirow[t]{2}{*}{ Average EIB score } & Mean & \multicolumn{2}{|c|}{96.0} & \multicolumn{2}{|c|}{84.7} & $<0.000$ * \\
\hline & $95 \% \mathrm{CI}$ & \multicolumn{2}{|c|}{$94.6-97.4$} & \multicolumn{2}{|c|}{$82.7-96.7$} & \\
\hline \multirow[t]{8}{*}{ Respondent's score } & 78.1 & 0 & 0 & 6 & 20.7 & \\
\hline & 81.3 & 0 & 0 & 7 & 24.1 & \\
\hline & 84.4 & 0 & 0 & 3 & 10.3 & \\
\hline & 87.5 & 2 & 6.9 & 8 & 27.6 & \\
\hline & 90.6 & 2 & 6.9 & 1 & 3.4 & \\
\hline & 93.8 & 7 & 24.1 & 4 & 13.8 & \\
\hline & 96.9 & 9 & 31 & & & \\
\hline & 100 & 9 & 31 & & & \\
\hline
\end{tabular}

Notes: $*$ p-value $<0.05, \mathrm{CI}=$ Confidence Interval, EIB = Early Initiation of Breastfeeding 
Table 3. The Effect of the Use of the Information, Education, and Communication Flowchart Media on the Early Initiation of Breastfeeding Implementation

\begin{tabular}{|c|c|c|c|c|c|c|}
\hline \multirow{2}{*}{ Variable } & \multirow{2}{*}{ Category } & \multicolumn{2}{|c|}{ Intervention Group } & \multicolumn{2}{|c|}{ Control Group } & \multirow{2}{*}{ p-value } \\
\hline & & $\mathbf{n}$ & $\%$ & $\mathbf{n}$ & $\%$ & \\
\hline \multirow[t]{2}{*}{ EIB succession } & Success & 27 & 93.1 & 6 & 20.7 & $<0.000^{*}$ \\
\hline & No Success & 2 & 6.9 & 23 & 79.3 & \\
\hline \multirow[t]{4}{*}{ EIB succession time } & Success in 1 hour & 19 & 65.5 & 6 & 20.7 & $0.000 *$ \\
\hline & Success in 2 hour & 8 & 27.6 & 0 & 0 & \\
\hline & Success in 3 hour & 0 & 0 & 0 & 0 & \\
\hline & No success & 2 & 6.9 & 23 & 79.3 & \\
\hline Total & & 29 & 100 & 29 & 100 & \\
\hline
\end{tabular}

Note: $*$ p-value $<0.05, \mathrm{EIB}=$ Early Initiation of Breastfeeding

Table 4. Factors Associated with Early Initiation of Breastfeeding

\begin{tabular}{lcrrcc}
\hline Variable & $\mathbf{n}$ & $\%$ & p-value & $\mathbf{R}^{2}$ & B-Coefficient \\
\hline IEC flowchart media & & & $<0.000^{*}$ & & 11.2 \\
Age & & & 0.355 & & 2.3 \\
Education & \multirow{2}{*}{100} & 0.247 & 0.636 & 1.7 \\
Work period & & & 0.343 & & 2.3 \\
Training & & & 0.444 & & 1.0 \\
\hline
\end{tabular}

Notes: ${ }^{*}$-value $<0.05$, EIC $=$ Information, Education, and Communication

tion and control groups were relatively similar. There were no differences in the characteristics (age, education, work period, and training) between the two groups, except for the knowledge variable. The knowledge in the intervention group was initially lower than that in the control group. However, this study demonstrated that after using the IEC flowchart media, printed on poster and booklet, the success rate of the EIB implementation was higher in the intervention than in the control group. The use of the IEC flowchart media can facilitate midwives in implementing EIB.

The results of this study indicated the importance of the IEC flowchart media in the implementation of EIB by midwives. The IEC flowchart media was able to improve the skills of midwives in facilitating EIB after childbirth. Statistically, there was a significant difference in the average EIB implementation score between the intervention and control groups. This result was in line with the studies conducted by Palupi, ${ }^{26,30}$ which indicated that there was a significant difference in the average EIB implementation score between the two groups. These findings were also supported by Gunawan, ${ }^{29}$ who stated that the provision of health education provides better knowledge and understanding of EIB. Knowledge is one of the factors that tend to affect the expected behavior. ${ }^{26}$ The use of the IEC flowchart media is expected to increase the knowledge of midwives and improve the ability of midwives to implement EIB.

The implementation of EIB is one of the steps in the
Normal Childbirth Care program that the Indonesia Midwives Association has determined; thus, it needs to be performed. The IEC flowchart media is significantly effective in increasing the accuracy of the EIB implementation and the potential for EIB success in the first one hour of life of the newborns. The standard procedure for the EIB implementation in the form of a flow chart is able to reduce the complexity of the actual situation of EIB in the health service. Midwives can easily implement EIB because the steps are presented on the flowchart chronologically, in detail, and clearly according to the situation that occurs. Moreover, the midwives can easily see the flow chart when facilitating EIB. The IEC flowchart media succeeded in solving complex problems about implementing EIB through simple steps at each stage so that the midwives easily understood it. 30

The results indicated a significant difference in the average EIB implementation score between the intervention and the control groups. The success rate of midwives in performing EIB in less than one hour was higher in the intervention group $(93.1 \%)$ than in the control group $(65.5 \%)$. The increased success of the EIB implementation within one hour may be due to the correct placement of the baby on the mother's chest, as stated in the IEC flowchart media, making it easier for the baby to find and suckle the mother's nipple.

The implementation of EIB is hindered by time constraints, ${ }^{31,32}$ and other activities still need to be done, such as weighing the baby and immunizations. ${ }^{33}$ In health services, with existing routines and patients, the midwives have limited time in assisting mothers with EIB; therefore, it is important for the midwives to establish conducive practices in performing EIB effectively after birth. ${ }^{34}$ This study demonstrated that using the IEC flowchart media, the implementation of EIB became more effective and successful within one hour.

After the first hour had passed, there was still an increase in the number of babies who managed to find the mother's nipple and suckle in the intervention group, 
while in the control group, there was no addition. This situation indicated that the IEC flowchart media could increase the success rate of the EIB because the stages were already displayed on the flowchart in detail, which facilitates the midwives in performing EIB. If the baby has not yet been able to suckle within the first hour, the EIB process should be continued by bringing the baby closer to the nipple and allowing skin-to-skin contact between the mother and baby for the next 30-60 minutes.

This study demonstrated that the IEC flowchart media was the most dominant factor in successful EIB implementation. This result indicated that using the IEC flowchart media could facilitate midwives in performing EIB. Furthermore, the IEC flowchart media provided clear and step-by-step guidance in addressing the complexities of the actual situation in the implementation of EIB in health services.

The possibility biases were due to the lack of understanding of the data collectors when answering the questionnaires. The enumerators were trained before entering the field to prevent the problems from happening. The scope of this study was limited to the field area of research, and further research is needed to confirm the benefits of the IEC flowchart media.

\section{Conclusion}

The results of this study indicate that the average EIB implementation scores of both groups are different. The group of midwives who received IEC flowchart media was significantly higher than midwives who did not receive IEC flowchart media. The success rate of the midwives who were given IEC flowchart media for the EIB implementation was also higher than that of the control group. The implementation of EIB by midwives can be improved through the provision of the IEC flowchart media installed or affixed in places where childbirth occurs so the midwives can easily see it.

\section{Abbreviations \\ EIB: Early initiation of breastfeeding; IEC: Information, Education, and Communication; PHC: Primary Health Care; WHO: World Health Organization; Riskesdas: Riset Kesehatan Dasar; IPR: Intellectual Property Rights; DIII: Diploma-III.}

\section{Ethics Approval and Consent to Participate}

Ethics approval was obtained from the Faculty of Public Health Universitas Indonesia (No. Ref. 61/UN2.F10/PPM.00.02/2019). All of the respondents could refuse to participate in the study and were given an agreement form before filling in the questionnaires.

\section{Competing Interest}

The author declares that there is no significant competing financial, professional, or personal interest that might have affected the performance or presentation of the work described in this manuscript.

\section{Availability of Data and Materials}

Data and materials of this study can be obtained upon request.

\section{Authors' Contribution}

AFF designed, conceptualized, collected, and analyzed the data of the study. RN was involved in the writing of the manuscript while SF directed and supervised this study right from the beginning, overviewed, and gave final approval to the manuscript.

\section{Acknowledgment}

The authors would like to thank the Primary Health Care (PHC)s of Tanah Saeral, Pasir Mulya, Cipaku, Merdeka, East Bogor, Central Bogor, North Bogor, and Tegal Gundil for the permission and facilities to complete this research. The authors also want to thank respondents for their willingness to participate and the enumerators for their commitment.

\section{References}

1. Alifariki LO, Kusnan A, La R. Proxy determinant factors of neonatal mortality rate in the working area of North Buton District Health Office. BKM J Community Med Public Heal. 2019; 35( 4): 131-8.

2. Mujiati, Novianti. Dissemination implementation of early breastfeeding initiation in St. Carolus Hospital and Budhi Asih Regional General Hospital Jakarta. Bul Penelit Kesehat. 2016; 43 (4): 247-56.

3. World Bank. Mortality rate, neonatal (per 1.000 live births); 2021.

4. United Nations International Children's Emergency Fund. Levels \& trends in child mortality report 2017. New York; 2017.

5. Nur A, Marissa N. Breastfeeding history with infectious disease in toddlers. Kesmas Natl Public Heal J. 2014; 9 (2): 144-9.

6. Sharma IK, Byrne A. Early initiation of breastfeeding: a systematic literature review of factors and barriers in South Asia. Int Breastfeed J. 2016; 11 (17): 1-12.

7. Susilowati, Kusharisupeni, Fikawati S, Achmad K. Breast-feeding duration and children's nutritional status at age 12-24 months. Paediatr Indones. 2016; 50 (1): 56-61.

8. Suryani D, Simbolon D, Elly N, Pratiwi BA, Yandrizal Y. Determinants failure of exclusive breast feeding on health in the City Bengkulu. J Kesehat Masy. 2017; 12 (2): 304-12.

9. Novianti, Rizkianti A. Health professional's support breastfeeding initiation: case study in a private and governement hospital in Jakarta. J Kesehat Reproduksi. 2016; 7 (2): 95-108.

10. United Nations International Children's Emergency Fund. Breast crawl: initiation of breastfeeding by breast crawl. Mumbai: UNICEF Maharashtra; 2007.

11. Edmond KM, Zandoh C, Quigley MA, Amenga-Etego S, Owusu-Agyei $\mathrm{S}$, Kirkwood BR. Delayed breastfeeding initiation increases risk of neonatal mortality. Pediatrics. 2006; 117 (3).

12. Fikawati S, Syafiq A. The relationship between immediate breastfeeding and exclusive breastfeeding up to 4-months. J Kedokt Trisakti. 2003; 22 (2): 47-55.

13. Fikawati S, Syafiq A. Penyebab keberhasilan dan kegagalan praktik pemberian ASI eksklusif. Kesmas Natl Public Heal J. 2009; 4(3): 12031. 
14. United Nations International Children's Emergency Fund. Children in a digital world. New York; 2017.

15. Kementerian Kesehatan Republik Indonesia. Results of nutrition status monitoring in 2017. Kementerian Kesehatan RI. 2017 p. 1-150.

16. Ariyani DF, Handayani L. Contribution factors on early initiation of breastfeeding. Int J Public Heal Sci. 2015; 4 (3): 192.

17. Noer ER, Muis SF, Aruben R. Praktik inisiasi menyusu dini dan pemberian ASI eksklusif: studi kualitatif pada dua puskesmas, Kota Semarang. Media Med Indones. 2011; 45 (3): 144-50.

18. Gleeson D, Flowers K, Fenwick J. Midwives' time and presence: a key factor in facilitating breastfeeding support for new mothers. Int J Childbirth. 2014; 4 (4): 219-27.

19. Syam A, Amiruddin R. Inhibitor factors of early initiation of breastfeeding among mothers in Rural District Bone, South Sulawesi, Indonesia. Asian J Epidemiol. 2015; 8 (1): 1-8.

20. Legawati, Dasuki D, Julia M. Effect of early initiation of breastfeeding to the first month practice of breastfeeding. J Gizi Klin Indones. 2011; 8 (2): 60-8.

21. Bernolian N, Sjaaf AC. The evaluation of early initiation breastfeeding implementation in dr. Mohammad Hoesin Hospital of Palembang, Indonesia: complaints and barriers. Glob Heal Manag J. 2017; 1(2): 53-60.

22. Wahyuningsih E. Analysis of early initiation of breastfeeding (EIB) implementation by inpatient public health center midwives in Sukoharjo. In: The 2nd University Coloqium; 2015.

23. Damayanti W. Analysis of the implementation of early breastfeeding initiation (EIB) at the Tangerang District Health Centre, Banten Province. Indones Midwifery J. 2016; 1 (1): 1-10.

24. Diba Faisal A, Serudji J, Ali H. Implementation of the early breastfeeding initiation program in the work area of the Lubuk Buaya Health Center, Koto Tangah District. J Kesehat Andalas. 2020; 8 (4): 1-9.

25. Siregar H, Sriatmi A, Kartika Wulan LR. Evaluation of early breastfeeding initiation program by midwives at Panti Wilasa Citarum
Hospital, Semarang. J Kesehat Masy. 2014; 2(2): 103-9.

26. Palupi RR. The use of communication, information, education media in the implementation of early initiation of breastfeeding by midwife in community health centres East Jakarta. Universitas Indonesia; 2018.

27. Dinas Kesehatan Jawa Barat. Profil kesehatan Provinsi Jawa Barat tahun 2016 (West Java Province health profile). 2016; 326.

28. Kementerian Kesehatan Republik Indonesia. Basic health research. Kementeri Kesehat RI; 2013.

29. Gunawan DCD. The effect of education class with accompanied by husband on breastfeeding knowledge and practice in pregnant women: case study at asosiasi ibu menyusui Indonesia (AIMI) in DKI Jakarta. Universitas Indonesia; 2013.

30. Syafiq A, Palupi RR, Fikawati S, Faradhil AF. Improving implementation of early initiation of breastfeeding through a standard procedure flowchart. Breastfeed Rev. 2021; 29 (2): 15-25.

31. Swerts M, Westhof E, Bogaerts A, Lemiengre J. Supporting breastfeeding women from the perspective of the midwife: a systematic review of the literature. Midwifery. 2016; 37: 32-40.

32. Schmied V, Gribble K, Sheehan A, Taylor C, Dykes FC. Ten steps or climbing a mountain: a study of Australian health professionals' perceptions of implementing the baby friendly health initiative to protect, promote and support breastfeeding. BMC Health Serv Res. 2011; 11: $1-10$.

33. Mgolozeli SE, Shilubane NH, Khoza LB. Midwives' perceptions of skin-to-skin contact between the mother and baby after birth in selected rural primary healthcare facilities in Schoonoord, Limpopo province, South Africa. African J Phys Act Heal Sci. 2018: 28-39.

34. Cooke M, Cantrill RM, Creedy DK. Midwives' reported practice supporting the first breastfeed. Maternal and Child Nutrition. 2009; 5: 334-46. 